Review

\title{
Lipids of Prokaryotic Origin at the Base of Marine Food Webs
}

\section{Carla C. C. R. de Carvalho ${ }^{1, *}$ and Maria José Caramujo ${ }^{2}$}

1 IBB-Institute for Biotechnology and Bioengineering, Centre for Biological and Chemical Engineering, Department of Bioengineering, Instituto Superior Técnico, Technical University of Lisbon, Av. Rovisco Pais, Lisbon 1049-001, Portugal

2 Centre for Environmental Biology, Faculty of Sciences, University of Lisbon, Campo Grande C2, Lisbon 1749-016, Portugal; E-Mail: mj.caramujo@fc.ul.pt

* Author to whom correspondence should be addressed; E-Mail: ccarvalho@ist.utl.pt; Tel.: +351-218-419-594; Fax: +351-218-419-062.

Received: 8 October 2012; in revised form: 14 November 2012 / Accepted: 22 November 2012 / Published: 29 November 2012

\begin{abstract}
In particular niches of the marine environment, such as abyssal trenches, icy waters and hot vents, the base of the food web is composed of bacteria and archaea that have developed strategies to survive and thrive under the most extreme conditions. Some of these organisms are considered "extremophiles" and modulate the fatty acid composition of their phospholipids to maintain the adequate fluidity of the cellular membrane under cold/hot temperatures, elevated pressure, high/low salinity and $\mathrm{pH}$. Bacterial cells are even able to produce polyunsaturated fatty acids, contrarily to what was considered until the 1990s, helping the regulation of the membrane fluidity triggered by temperature and pressure and providing protection from oxidative stress. In marine ecosystems, bacteria may either act as a sink of carbon, contribute to nutrient recycling to photo-autotrophs or bacterial organic matter may be transferred to other trophic links in aquatic food webs. The present work aims to provide a comprehensive review on lipid production in bacteria and archaea and to discuss how their lipids, of both heterotrophic and chemoautotrophic origin, contribute to marine food webs.
\end{abstract}

Keywords: phospholipid; fatty acids; polyunsaturated fatty acids; extremophile; bacteria; archaea; trophic web 


\section{Introduction}

The conditions of the marine environment led to the development of specialized lipid molecules responsible for the formation of membranes and storage of energy, and in higher organisms, for tissue formation, reproduction and growth. Fatty acids (FA) are important lipid compounds that are used as building blocks for the majority of lipid classes and as precursors for the biosynthesis of bioactive molecules. The fatty acid composition of phospholipids and their interaction with sterols and proteins determine the physical properties of cellular membranes, whilst neutral lipids, such as triacylglycerols (TAGs) and wax esters (WE), are reserves of fatty acids for energetic purposes and for phospholipid synthesis.

Marine bacteria use adaptive changes in lipid composition as a response to environmental variations in pressure, temperature and salinity [1]. Archaea, which constitute a significant fraction of the "picoplankton" in the dark ocean water below $150 \mathrm{~m}$, and equal bacteria in numbers at depths greater than $1000 \mathrm{~m}$ [2], are adapted to life in extreme environments, such as hot vents, and contain a much more stable membrane than bacteria. Bacterial membranes contain phospholipids in which the fatty acid moieties are linked by ester bonds to glycerol and form a phospholipid bilayer. However, archaeal membranes have bipolar lipids containing two polar heads linked by isoprenoid chains and ether linkages to glycerol. This allows for the formation of a monolayer membrane, which is likely to be responsible for the ability of these cells to thrive in extreme environments. Other features distinguishing archaeal and bacterial lipids include: the glycerophosphate backbone of archaeal phospholipids is $s n$-glycerol-1-phosphate, while bacterial have a $s n$-glycerol-3-phosphate backbone; the majority of the isoprenoid hydrocarbon chains of polar lipids in archaea are methyl-branched, whilst their bacteria counterparts are mostly straight-chain fatty acids; and several archaeal species present bipolar lipids with a tetraether core [3].

The development of mass spectrometry equipment and techniques has enabled the determination of structure and function of lipids in living systems and the emergence of lipidomics as an important part of metabolomics. There are two approaches in mass spectrometry-based lipidomics: one is based on a separation of lipids into different classes prior to analysis, whilst the other uses a shotgun approach in which all lipid species are analyzed simultaneously without a prior separation [4,5]. Novel lipid species can also be discovered by operating mass spectrometers in full-scan mode to search for new mass-to-charge ratio peaks [4]. In the field of marine lipidology, these different approaches can be used to search for new fatty acid structures and new sources of polyunsaturated fatty acids (PUFAs), in studying the role of the several fatty acids in cell membranes and their biosynthetic pathways and in finding the best fatty acid biomarkers or fatty acid ratios to assess trophic transfer in ecosystems [6].

The recognition that PUFAs, especially docosahexaenoic (22:603 or DHA) and eicosapentaenoic (20:503 or EPA) acids, are fundamental to promote human health, by helping brain function and preventing cardiovascular diseases, increased the interest in these fatty acids [7-9]. The current global market for $\omega 3$ fatty acids is estimated to be 15,000-20,000 tons, derived from an approximate world production of fish oil of 300,000 tons per year [10]. Recent studies have shown that marine phospholipids have a better bioavailability, resistance to oxidation and a higher content of EPA and DHA than oily triglycerides from the same source [11,12]. Until the 1990s, it was considered that bacteria had no PUFA, with the exception of selected cyanobacteria. As noted by Okuyama et al. [13], 
such assumption may have resulted from the fact that the bacterial species whose physiology, biochemistry and molecular biology had been well studied until that time were mesophilic species, such as Escherichia coli, which have no PUFA. Additionally, the culture conditions may determine the bacterial EPA content that is dependent on $\mathrm{pH}$, temperature and other growth conditions [14]. It is now accepted that some species have the capacity to produce EPA, DHA or arachidonic acid (20:4 6 , ARA) [15]. As pointed out in a review by Valentine and Valentine, PUFAs have significant structural roles in bacterial membranes, including: regulatory function triggered by temperature and pressure; EPA-enriched membranes support a respiratory lifestyle dependent on proton bioenergetics; and contribution to increased fluidity of the cellular membrane under marine conditions [16]. DHA and EPA should also protect the marine organisms from biotic and abiotic oxidative stresses caused by reactive oxygen species (ROS), which are prevalent in marine environments [17]. Although, polyunsaturated fatty acids, such as EPA and DHA, are very susceptible to oxygen and ROS, several studies indicate that these molecules are rather stable against oxidative stresses when they are in vivo [17-19].

The concept of FA being transferred conservatively through aquatic food webs and of their use as biomarkers was first suggested in 1935 by Lovern [20] and applied to trace the diet in marine environments in the 1960s by Ackman and Eaton. As a result, FA biomarker analyses have become an important tool for resolving trophic interactions in marine ecosystems [21]. The use of bacterial fatty acids or bacterial fatty acid ratios may thus be used to disclose bacterial connections to the marine food web and its importance to supply materials and energy to the higher trophic levels.

\section{Lipid Production in Marine Micro-Organisms}

Bacteria must be able to maintain the biological functions and integrity of the cellular membrane under stressful conditions, as this structure is responsible for controlling the entrance of solutes in the cell, for the maintenance of energy status, for signal transduction and for keeping turgor pressure. Lipids play an important role in the maintenance of cell viability under stressful conditions, as membrane fluidity is maintained by alterations in the fatty acid composition of the membrane phospholipids through a mechanism called "homeoviscous adaptation" [22]. However, several other lipid molecules, such as extracellular glycolipids, energy storage molecules, such as triacylglicerides, and defense lipids with antibacterial properties to fight competitors are also of paramount importance in marine environments.

\subsection{Lipids as Protecting Agents in Marine Environments}

Some of the marine environments, including hot vents, polar icy waters, acidic and alkaline waters, salt brines and pressurized abyssal trenches, present conditions so hostile to humans that they were initially considered too extreme to support microbial life. However, as sampling and laboratorial culture conditions techniques evolved, it was found that microbial "extremophiles" could survive and thrive in such environments [23]. They were named according to their optimal growth conditions as thermophiles $\left(\mathrm{T}_{\mathrm{opt}}>60{ }^{\circ} \mathrm{C}\right)$, hyperthermophiles $\left(\mathrm{T}_{\mathrm{opt}}>80{ }^{\circ} \mathrm{C}\right)$, psychrophiles $\left(\mathrm{T}_{\mathrm{opt}}<15{ }^{\circ} \mathrm{C}\right)$, acidophiles $\left(\mathrm{pH}_{\mathrm{opt}}<3\right)$, alkaliphiles $\left(\mathrm{pH}_{\mathrm{opt}}>8.5\right)$, halophiles $(\mathrm{NaCl}>3 \%)$ and barophiles, or 
piezophiles. A few bacterial strains can endure both elevated temperature and extreme $\mathrm{pH}$, being considered poly-extremophiles [24].

Extremophiles can be (i) obligate extremophiles, which only grow under one or more extreme conditions, and (ii) facultative extremophiles, which grow optimally at a non-extreme condition but can tolerate and thrive under conditions that are lethal or toxic to the majority of living organisms. Extremophiles present alterations in fatty acid composition of the cellular membranes and produce specialized lipids, allowing them to survive under conditions that kill most of the other micro-organisms.

Most of the marine environment is characterized by a temperature below $4{ }^{\circ} \mathrm{C}$ and pressure above $100 \times 10^{5} \mathrm{~Pa}$, favoring psychrophilic and barophilic bacteria [25]. During a one-year study with monthly sampling throughout the water column (from surface to $4750 \mathrm{~m}$ deep) in Hawaii, it was found that pelagic crenarchaeota, a group of archaea, was equivalent in cell numbers to bacteria at depths greater than $1000 \mathrm{~m}[2]$. The authors estimated that the global oceans harbor approximately $1.3 \times 10^{28}$ archaeal cells and $3.1 \times 10^{28}$ bacterial cells. Biogeochemical and stable carbon isotopic analyses of a sedimentary record of archaeal lipids indicate that an anoxic event in Earth history led certain hyperthermophilic Archaea to adapt to low-temperature environments and to their massive expansion [26]. In subsurface sediments, buried deeper than $1 \mathrm{~m}$ in a wide range of oceanographic settings, it was found that at least $87 \%$ of intact polar membrane lipids could be attributable to archaeal membranes [27].

The fatty acid composition of the membrane phospholipids regulates membrane fluidity. At extremely low temperatures, an increase in the content of unsaturated and polyunsaturated fatty acids and a decrease in the average chain length of fatty acids in cellular membranes is observed [28,29]. Several psychrophilic bacterial strains isolated from sea ice produce a novel enzyme family required for the biosynthesis of PUFAs at low temperatures called polyketide synthase (PKS) [30,31]. The genes encoding these enzymes responsible for de novo long-chain PUFA biosynthesis are designated $p f a E A B C D$ and were thought to exist in the narrow subset of marine bacteria able to produce long-chain fatty acids [32]. However, the genetic potential to produce long-chain fatty acids via a FAS/PKS mechanism seems to be scattered throughout the bacterial domain [32]. During a stepwise adaptation of Rhodococcus erythropolis DCL14 cells from optimal growth conditions $\left(28^{\circ} \mathrm{C}, \mathrm{pH} 7.0\right)$ to extreme conditions (that previously killed non-adapted cells) [13], it was found that the cells produced increased amounts of polyunsaturated fatty acids at lower temperatures and in the presence of copper sulphate (Figure 1). The cells produced 2.4 and 3.6 times more PUFAs at 15 and $4{ }^{\circ} \mathrm{C}$, respectively, than at $28{ }^{\circ} \mathrm{C}$ (Figure 1A). A dose-dependent increase in the content of PUFAs was observed with copper sulphate for concentrations higher than $0.03 \%(\mathrm{w} / \mathrm{v})$, reaching a 3.7 -fold increase at $1 \%$ (Figure 1D). The $\mathrm{pH}$ and salt concentration did not significantly affected PUFA production in R. erythropolis (Figure 1B,C). A type Q gene cluster homologous to the $p f a$ genes had been found in R. erythropolis PR4 [32]. 
Figure 1. Production of polyunsaturated fatty acids in R. erythropolis during adaptation to temperature (A), $\mathrm{pH}(\mathbf{B})$, high concentration of salt (C) or copper sulphate (D).
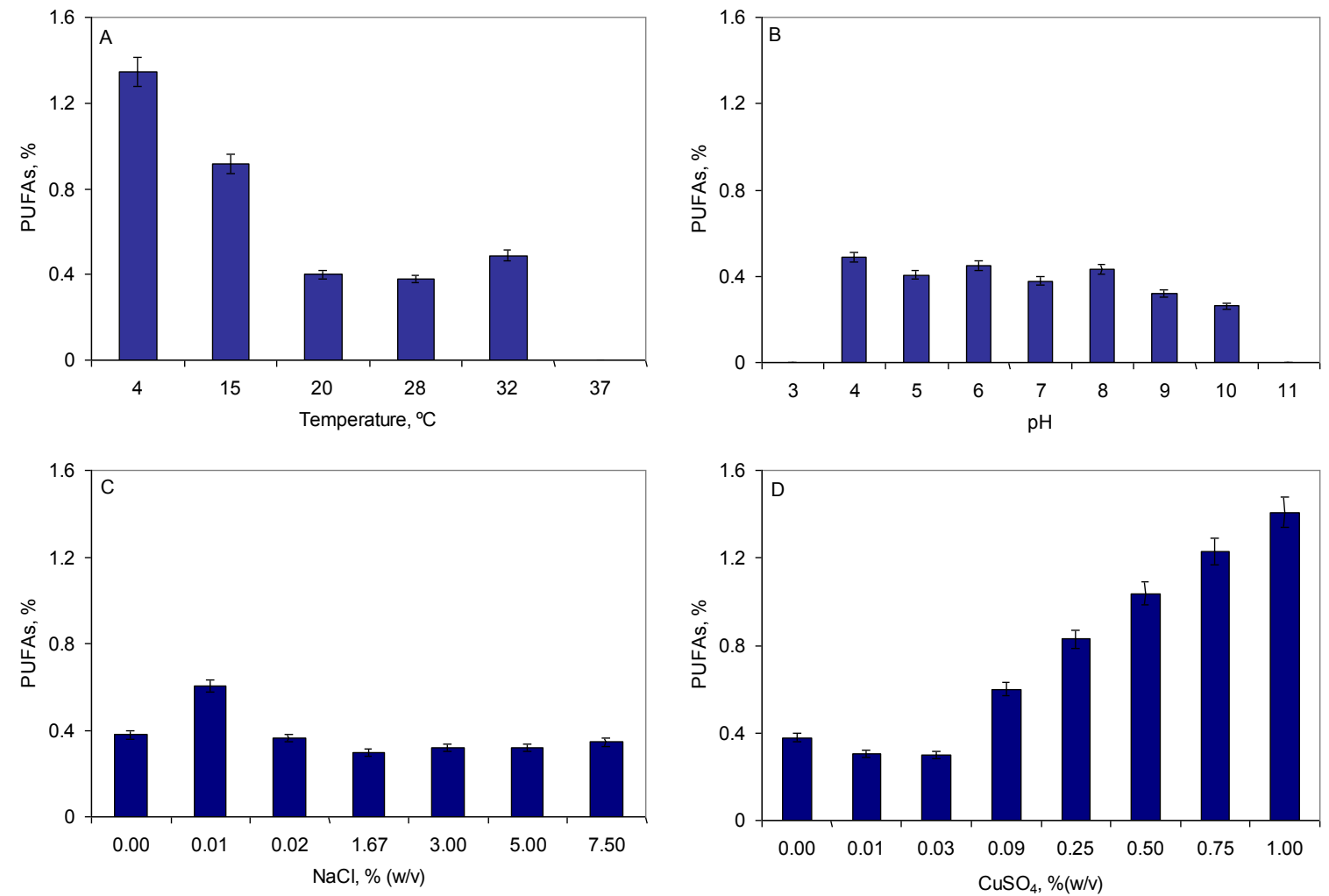

Lipids are known to be heat-sensitive, and hyperthermophile bacteria produce special lipids. The bacterium Thermotoga maritima, which presents one of the highest growth temperatures at $90{ }^{\circ} \mathrm{C}$, contains a novel glycerol ether lipid called 15,16-dimethyl-30-glyceryloxy-triacontanedioic acid that confers protection against hydrolysis at high temperatures [33]. The lipids of thermophilic archaea are characterized by unique structural features: they contain isoprenoid (phytanyl) chains with 15, 20, 25 or 40 carbons instead of straight chains observed in other organisms; two of these chains are linked via ether linkages to glycerol or a polyol; the glycerol found in archaea, 2,3-di-O-sn-glycerol, has the reverse stereochemistry when compared to that found in other organisms [34]. The ether lipids derived from diphytanyl-glycerol, or from its dimer di(biphytanyl)-diglycerol, are present on all archaeal membranes and confer to the cells a remarkable resistance against hydrolysis at high temperatures and acidic $\mathrm{pH}$ [35]. Furthermore, at high temperatures, an increased degree of cyclization of the aliphatic core of archaeal membranes is observed with a larger ratio of tetraether lipids $v s$. diether lipids, and the number of cyclopentane rings can vary up to four per aliphatic chain, thus maintaining membrane fluidity [36,37].

At high temperatures, thermophiles have problems keeping the intracellular concentration of $\mathrm{Na}^{+}$, since at a high temperature, the cell membrane becomes more permeable to the diffusion of protons and sodium ions [38]. Higher salinity concentrations cause, in general, an increase in the content of negatively charged phospholipids at the expense of neutral phospholipids. Gram-negative bacteria decrease the proportion of zwitterionic phosphatidylethanolamine in the membrane, while increasing the proportion of negatively charged phosphatidylglycerol and/or diphosphatidylglycerol $[39,40]$. In 
gram-positive bacteria, the anionic lipid fraction increases with salinity as a result of a higher content of diphosphatidylglycerol rather than phosphatidylglycerol [40].

When the transcriptional profiling of the halophile Halobacterium sp. NRC-1, which was among the first Archaea to be completely sequenced, was studied, it was found that growth at cold temperatures altered the expression of genes involved in lipid metabolism [41]. The gene coding for $s n$-1-glycerol phosphate dehydrogenase, responsible for the first step in the synthesis of polar lipids, was down regulated by 2.7-fold, while up-regulation was observed in the genes encoding for dehydrogenases for increased turnover of polar lipids, for a long-chain fatty acid-CoA ligase and for acetoacetyl-CoA thiolase, allowing the strain to alter the composition in lipids in the cold.

The fluidizing properties of EPA/DHA on cellular membranes seem a key point in barophilic bacteria, which have to carry out respiration at temperatures near $0{ }^{\circ} \mathrm{C}$ and under extremely high hydrostatic pressure. In Acholeoplasma laidlawii, when only $50 \%$ of the total lipids are in the fluid state, bacteria can still slowly grow and replicate, but growth ceases when around $90 \%$ of the membrane lipids pass from the liquid crystalline to the gel phase [42]. Although DHA and EPA phospholipids have an important role in disrupting or blocking the formation of islands of gel-phase lipids, there could be more fluidizing processes or lipids involved [15].

Two barophilic bacteria isolated from sediments from the Marianas Trench, DB21MT-2 and DB21MT-5, presented novel phospholipids in the classes of phosphatidylglycerol (PG) and phosphatidylethanolamine (PE) and its derivatives, phosphatidylmethylethanolamine (PME) and phosphatidyldimethylethanolamine (PDME) [43]. The phospholipids contained a high amount of

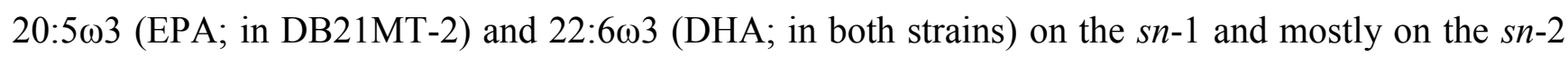
position of the phospholipids. Furthermore, the PUFAs were associated with almost every PG molecule, which was expected to cause greater disruption in acyl chain packing due to the larger head group of this phospholipid. The studies by Fang et al. [43] also suggested that psychrophilic and barophilic bacteria should be the major contributors of PUFAs to deep-sea sediments, since the vertical flux of PUFAs from surface water plankton decrease rapidly with depth.

\subsection{Production of Specialized Lipids}

The marine environment has favored the production of unique fatty acids and lipid molecules (Table 1). Bacterial fatty acids that can be used as biomarkers in marine environment are typically odd-numbered, branched trans-unsaturated and cyclopropyl fatty acids, e.g., 15:0, 17:0, 10-methyl-16:0, iso- and anteiso-branched saturated and monounsaturated [5]. Besides phospholipids, fatty acids are the building blocks of other lipid classes, including ceramides, wax esters, glycosphingolipids and $\mathrm{N}$-acylated lipid molecules. Cyanobacteria are a source of acylated lipids and fatty acid amides [5]. The marine cyanobacterium Oscillatoria sp. produces a new diacylgalactolipid comprising 9,12-octadecadienoyl and 4-hexadecenoyl chains [44], whilst Lyngbya majuscule produces bioactive secondary malyngamides, such as Malyngamide $\mathrm{G}$ and 7-methoxydodec-4(E)-enoic acid $[45,46]$.

Extremophiles are also good sources of unusual fatty acids. Psychrophilic Bacillus species produce relatively rare $\Delta^{5}$-isomers, although no obvious advantage for growth at low temperature is provided by these isomers when compared to membrane lipids with $\Delta^{9}$ - or $\Delta^{11}$-isomers [47]. Bacteroides fragilis produces a branched-chain hydroxyl fatty acid in the amide for 3-hydroxy-15-methylhexadecanoic 
acid in lipopolysaccharides, which is rather specific in gram-negative bacteria [48]. The archaea Thermoplasma acidophilum, whose optimal growth conditions are $55-59{ }^{\circ} \mathrm{C}$ and $\mathrm{pH} 1-2$, produces a peculiar membrane with $82 \%$ polar lipids having as the main polar lipid a bipolar tetraether lipid with a phosphoglycerol and a $\beta$-L-gulopyranose as head groups and up to four cyclopentane rings per aliphatic chain [37].

Table 1. Unusual lipids produced by micro-organisms.

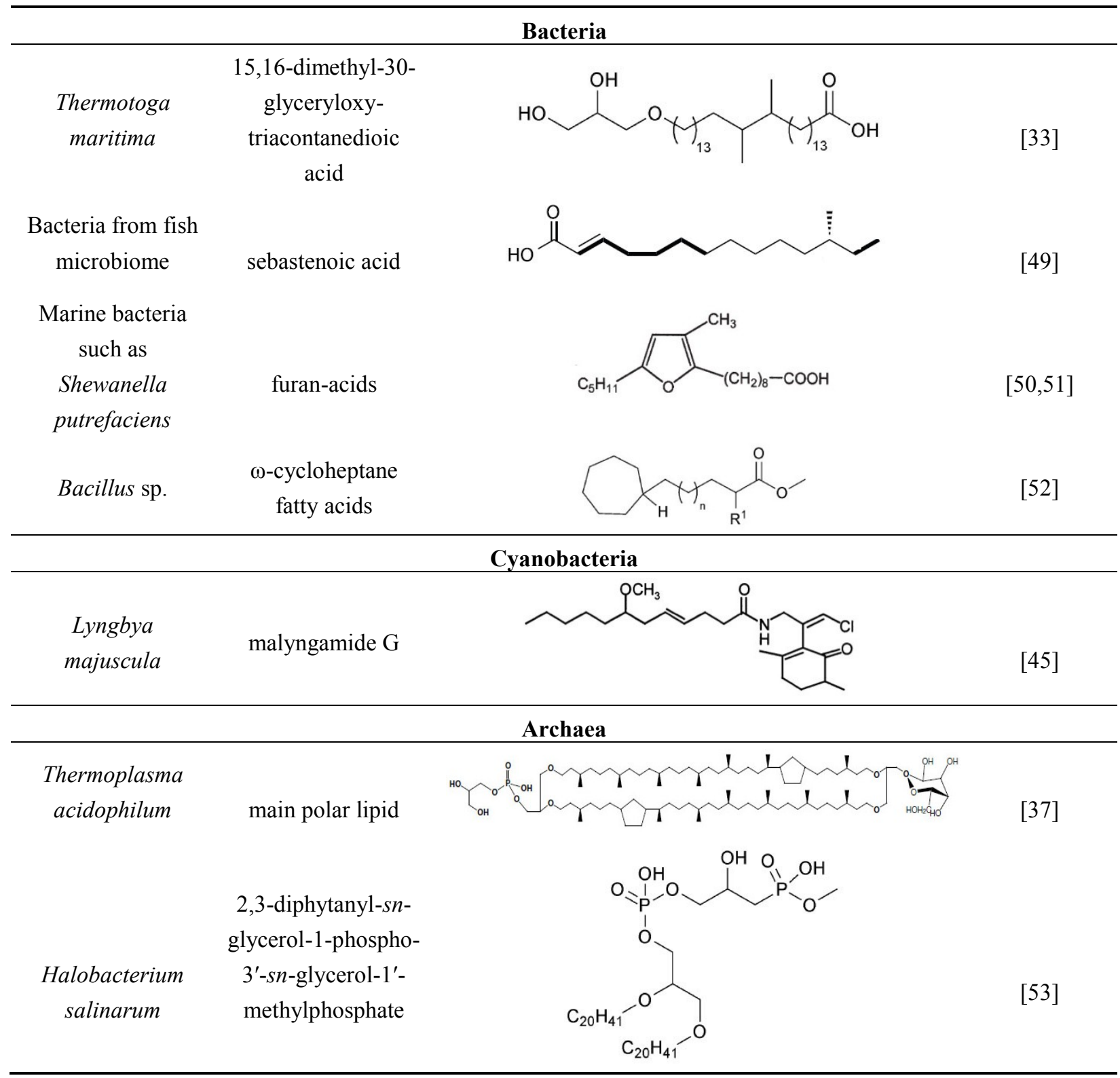

In a recently published paper, Sanchez et al. [49] examined for the first time a fish microbiome to isolate bacteria able to produce unique marine natural products. The fish intestines were a source of Actinomycetales, as well as unique strains of Firmicutes and Proteobacteria. The chemical extracts contained a new bioactive lipid called sebastenoic acid, which has anti-microbial activity against Staphylococcus aureus, Bacillus subtilis, Enterococcus faecium and Vibrio mimicus.

Furan fatty acids, shown to be scavengers of hydroxyl and peroxyl radicals and to provide potential protective properties in mammalian tissue and blood, have been found in, e.g., marine sponges, algae, 
plants and also in marine bacteria, such as Shewanella putrefaciens [50,51]. These acids are tri- or tetra-substituted furan derivatives characterized by either a propyl or pentyl side chain in one of the $\alpha$-positions and a substituted straight long-chain saturated acid with a carboxylic group at its end on the other.

\subsection{Non-Polar Phospholipids, Non-Phosphorous Polar Lipids and Neutral Lipids}

The analyses of phospholipid-based fatty acids (PLFAs) were introduced as a means to assess live bacterial biomass, since they are rapidly degraded after cell death [21]. However a surface sediment from Carteau cove, France, contained, apart from phospholipids, non-phospholipid polar compounds with 12- to 28-carbon atoms, which cautions against the use of PLFAs to assess bacterial biomass without preliminary analysis and purification of phospholipids [54].

Some bacteria incorporate fatty acids containing furan in their phospholipids. Among the species able to produce furan acids are Shewanella putrefaciens, Marinomonas comunis, Enterobacter agglomerans and Pseudomonas fluorescens, which were isolated from the intestinal liquor of fishes [55]. It was proposed that in marine bacteria living in fish, furan acids are generated by incorporation of a methyl group into cis-vaccenic acid, followed by introduction of a second double bond, and the diunsaturated fatty acid formed is presumed to react with oxygen, followed by ring closure, to assume the final furan acid structure [51]. These acids present a radical-scavenging ability and should help in protecting the cells [50].

Marine oil-degrading or hydrocarbonoclastic bacteria usually produce significant amounts of neutral lipids, which can be used as storage compounds, probably as a result of sporadic availability of hydrocarbons as growth substrates [56,57]. Among these compounds are triacylglycerols, diacylglycerols, wax esters and polyhydroxyalkanoates. The marine hydrocarbonoclastic bacterium Marinobacter sp. PAD-2 produced extracellular wax ester-like compounds when grown on hexadecane or succinate as the sole carbon source [57]. When Alvarez et al. tested forty psychrophile or psychrotrophic crude oil-utilizing bacteria, they found that around $73 \%$ of the strains were able to accumulate specialized lipids, such as polyhydroalkanoic acids (PHAs), and two strains were able to produce wax esters as storage compounds [56]. PHA accumulation was predominantly observed between 4 and $20^{\circ} \mathrm{C}$.

A R. erythropolis strain, able to degrade hydrocarbons and fuel oil under saline conditions [58], produces and excretes a trehalose based glycolipid to increase the bioavailability of hydrocarbons with reduced water solubility, and also when the cells are dehydrated (Figure 2). Extracellular polymeric substances provide protection for microbial cells, resulting in increased resilience under stressful periods [59]. Among the best examples of temporary stresses are marine intertidal conditions. In this case, micro-organisms are mainly in immobilized communities called biofilms, which confer protection against high temperature and exposure to ultraviolet radiation, temporary dehydration, limited access to nutrients and competition [60]. Curiously, intertidal bacteria have also been found to be a good source of PUFAs, with Shewanella colwelliana, Vibrio splendidus and Photobacterium lipolyticum being isolated from anoxic intertidal sediments [61]. 
Figure 2. Nile Red staining of extracellular glycolipids produced by $R$. erythropolis during dehydration.
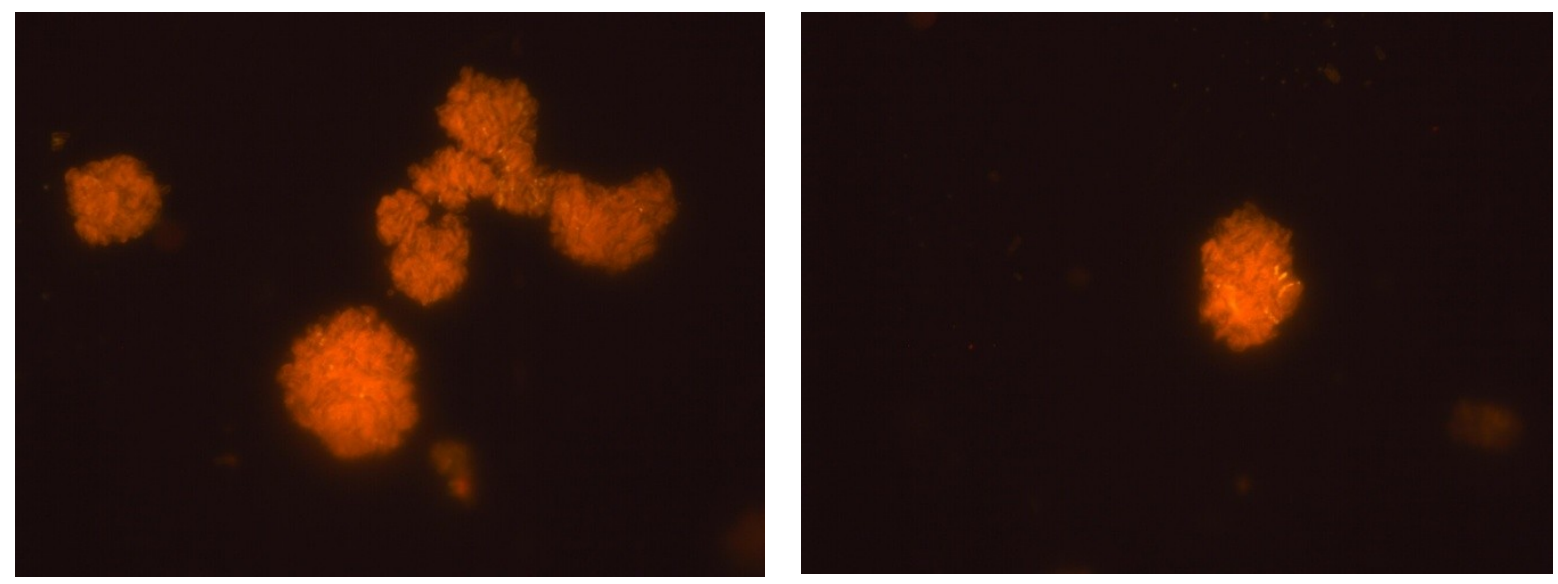

\section{Transfer of Bacterial Lipids to Metazoans in Marine Foodwebs}

Bacteria may either act as a sink of carbon in aquatic ecosystems, contribute to nutrient recycling to autotrophs or bacterial organic matter may be transferred to other trophic links in aquatic foodwebs [62]. Either as the sole diet or associated with other dietary items, bacteria are ingested by small sized aquatic animals. Although concentrations of bacteria-derived FA, including odd-numbered saturated, branched-chain and monounsaturated (e.g., 18:1 107 ), are retained by macrozooplankton [20], the ecological significance of the bacterial FA retention in crustacean consumers is still unclear. The low dietary value of bacteria relative to that of photosynthetic autotrophs (e.g., diatoms) and flagellates for the higher trophic links of the aquatic foodwebs has been associated with the poor value of its lipid composition, especially that of polyunsaturated fatty acids (PUFA) and sterol [63-65].

PUFA are involved in the regulation of physiological processes by serving as precursors in the biosynthesis of bioactive molecules, and both PUFA and sterols are essential major membrane constituents of crustacean zooplankton, zoobenthos and fish [66,67]. According to Brett \& Müller-Navarra [66], all herbivores convert the short-chain PUFA (i.e., with $<20$ carbons) $\alpha$-linolenic acid (18:3 13 ) to long-chain PUFA (i.e., with $\geq 20$ carbons), such as EPA and DHA, albeit with different efficiency. In aquatic environments, most PUFA and sterols originate in the primary producers, essentially the photosynthetic autotrophs. Bacteria are generally poor in PUFA, especially long-chained PUFA. EPA-producing bacteria are not common in marine environments, yet Yazawa et al. [68] found 88 strains of bacteria capable of producing EPA out of 5000 strains screened. In fact, it was recently found that several marine bacteria contain EPA and DHA at levels as high as $25 \%$ of total membrane FA [69], and it is likely that the polyketide synthase (PKS) pathway for PUFA synthesis (that acts independently of FA elongase and desaturase activities to synthesize EPA directly) is widespread in marine bacteria [70]. Additionally, the culture conditions may determine the bacterial EPA content that is dependent on $\mathrm{pH}$, temperature and other growth conditions [13]. Some crustacean species and nematodes may directly feed on bacteria and act as the first consumers of primary production, forming an important link between the basis of marine food webs and the higher trophic levels, like large metazoans and fish [71-77]. Direct feeding on bacteria may be crucial for crustacean species living close to hydrothermal vents, high-pressure low-temperature deep-sea habitats and 
permanently cold marine environments [78], or when bacteria is the sole item available [77]. It is worthy to note that in both deep-sea habitats and in the anoxic sediment of intertidal flats, bacteria may produce PUFA [13,79-81]. Nevertheless, the ecological role played by bacteria in aquatic environments cannot be dissociated from that of heterotrophic protists (HP). Heterotrophy is practiced by "mixotrophic" protists that include flagellated phytoplankton that may ingest bacteria or other protists [82] and by heterotrophic protists that do not possess permanent chloroplasts and rely on other organisms for nutrition [83]. HP are important consumers of bacteria and phytoplankton in oceanic food webs $[83,84]$, act as regenerators of nutrients for further phytoplankton growth [85] and as a food resource for marine zooplankton [86,87]. Although HP have been described as early as the 1920s [88], their ecological importance was only fully appreciated when new analytical methods enabled their identification and quantification (e.g., epifluorescence microscopy and flow cytometry). The notion of a classical linear food chain in aquatic environments consisting of phytoplankton, zooplankton and fish predominated until the 1970s, and its replacement by the concept of a trophic web only gained ground in the 1980s [89-91]. In the trophic web concept, dissolved (DOM) and particulated organic matter (POM) consisting of detritus, heterotrophic bacteria and autotrophic phytoplankton are consumed by HP in a carbon-transfer pathway called the microbial food web. This microbial food web connects to the classical food chain that branches into a network of trophic links. Although picoplankton are responsible for the bulk of primary production in large parts of the marine environment (as well as lakes) [92-94], their small size makes them largely unavailable for direct consumption by crustacean zooplakton, which have difficulty in retaining these size particles in their filtering apparatus. In systems where microalgal species rich in high quality lipids (i.e., PUFA) dominate the phytoplankton and can be directly grazed by crustacean zooplankton, the trophic transfer from autotrophs to crustaceans via HP can be considered both as a loss of carbon (i.e., losses via respiration), as well as a loss of essential lipid compounds [95]. Nevertheless, HP feeding on nanophytoplankton and bacteria may biochemically enhance the quality of their prey, which led to the "trophic-upgrading" concept developed by Breteler et al. [96,97]. Thus, heterotrophic protists bridge the gap between the microbial loop and higher trophic levels by both repackaging their food and by increasing its nutritional value, which may be especially important when phytoplankton abundance is low or of reduced lipid quality and producers are dominated by prokaryotic picoplankton [97-99].

\subsection{Transfer and Transformation of Bacterial Fatty Acids to Protists}

The potentials for fatty acid and PUFA synthesis in HP are closely related to phylogenetic lineages (see Desvilettes \& Bec and references therein [95]). Nevertheless, previous studies have identified two main factors affecting the PUFA composition of HP related to their habitat (marine vs. freshwater) and diet origin (bacteria $v s$. algae). While in freshwater HP $\omega 6$ FA dominate PUFA, marine HP contain high levels of $\omega 3$ highly unsaturated FA (HUFA), like EPA and DHA [100,101]. Both marine and freshwater HP feeding on algae have a higher content of $\omega 3$ PUFA than when feeding on bacteria [102,103], probably resulting from the higher availability of $\omega 3$ PUFA in algae. Most protists synthesize PUFA through a series of aerobic desaturations and elongations of the 16:0 and 18:0 acids produced by fatty acid synthase (FAS). Marine protists, namely thraustochytrids, are also able to produce PUFA using the PKS pathway and accumulate them in triacylglycerols [104,105]. 
Thraustochytrids, which are abundant in the marine foodweb, may be an important source of PUFA for the higher trophic levels [106]. In fact, thraustochytrids that may feed on bacteria are considered an alternative to fish oils as a source of long-chain PUFA [102] and are established candidates for commercial production of DHA [107].

\section{2. "Transfer" of Sterol}

Bacteria usually do not produce sterols, although there is evidence that some eubacteria are capable of synthesizing sterols de novo (e.g., Methylococcus capsulatus [108]). Crustaceans usually obtain their sterols directly via algae or through HP that have been feeding on algae. Some heterotrophic flagellates have the ability to synthesize sterols de novo [98], although ciliates seem to lack this ability. In the absence of dietary sterols, as when feeding on bacteria, ciliates produce the pentacyclic triterpenoid alcohol tetrahymanol or hopanoids, which serve as sterol surrogates in cell membranes (see Martin-Creuzburg and von Elert, and reference therein [109]). Some crustaceans (e.g., copepods) may incorporate tetrahymanol into their tissues, which enables them to maintain minimal egg production. Nevertheless, as Martin-Creuzburg and von Elert noted, it hasn't been tested whether tetrahymanol or hopanoids improve the performance of crustaceans. Nevertheless, the production of sterols or functionally equivalent compounds, like tetrahymanol, by intermediary protozoans may improve carbon transfer efficiency via the microbial loop from nutritionally inadequate primary producers to metazoan grazers.

\section{Conclusions}

The ecological role played by bacteria in aquatic environments cannot be dissociated from that of heterotrophic protists. The efficiency of carbon transfer between bacteria and metazoans may be improved by intermediary protists, which elongate fatty acids and synthesize sterol or sterol surrogates.

\section{Acknowledgments}

The authors would like to thank Fundação para a Ciência e a Tecnologia, Portugal (program Ciência2007) for financial support. The study was partially supported by the project CHARCOScomBIO awarded by the EDP Fund for Biodiversity (EDP Foundation, Portugal).

\section{References}

1. De Carvalho, C.C.C.R.; Fernandes, P. Production of metabolites as bacterial responses to the marine environment. Mar. Drugs 2010, 8, 705-727.

2. Karner, M.B.; DeLong, E.F.; Karl, D.M. Archaeal dominance in the mesopelagic zone of the Pacific Ocean. Nature 2001, 409, 507-510.

3. Koga, Y.; Morii, H. Biosynthesis of ether-type polar lipids in Archaea and evolutionary considerations. Microbiol. Mol. Biol. Rev. 2007, 71, 97-120.

4. Han, X.; Gross, R.W. Global analyses of cellular lipidomes directly from crude extracts of biological samples by ESI mass spectrometry. J. Lipid Res. 2003, 44, 1071-1079. 
5. Harkewicz, R.; Dennis, E.A. Applications of mass spectrometry to lipids and membranes. Annu. Rev. Biochem. 2011, 80, 301-325.

6. Bergé, J.-P.; Barnathan, G. Fatty acids from lipids of marine organisms: Molecular biodiversity, roles as biomarkers, biologically active compounds, and economical aspects. Adv. Biochem. Eng. Biothchnol. 2005, 96, 49-125.

7. Mozaffarian, D.; Rimm, E.B. Fish intake, contaminants, and human health: Evaluating the risks and the benefits. JAMA 2006, 296, 1885-1899.

8. Calon, F. Omega-3 polyunsaturated fatty acids in Alzheimer's disease: Key questions and partial answers. Curr. Alzheimer Res. 2011, 8, 470-478.

9. Simopoulos, A.P. Evolutionary aspects of diet: The omega-6/omega-3 ratio and the brain. Mol. Neurobiol. 2011, 44, 203-215.

10. Lu, F.S.; Nielsen, N.S.; Timm-Heinrich, M.; Jacobsen, C. Oxidative stability of marine phospholipids in the liposomal form and their applications. Lipids 2011, 46, 3-23.

11. Wijendran, V.; Huang, M.-C.; Diau, G.-Y.; Boehm, G.; Nathanielsz, P.W.; Brenna, J.T. Efficacy of dietary arachidonic acid provided as triglyceride or phospholipid as substrates for brain arachidonic acid accretion in Baboon Neonates. Pediatr. Res. 2002, 51, 265-272.

12. Peng, J.; Larondelle, Y.; Pham, D.; Ackman, R.G.; Rollin, X. Polyunsaturated fatty acid profiles of whole body phospholipids and triacylglycerols in anadromous and landlocked Atlantic salmon (Salmo salar L.) fry. Comp. Biochem. Physiol. 2003, 134, 335-348.

13. Okuyama, H.; Orikasa, Y.; Nishida, T.; Watanabe, K.; Morita, N. Bacterial genes responsible for the biosynthesis of Eicosapentaenoic and Docosahexaenoic acids and their heterologous expression. Appl. Environ. Microbiol. 2007, 73, 665-670.

14. De Carvalho, C.C.C.R. Adaptation of Rhodococcus erythropolis cells for growth and bioremediation under extreme conditions. Res. Microbiol. 2012, 163, 125-136.

15. Russell, N.J.; Nichols, D.S. Polyunsaturated fatty acids in marine bacteria-A dogma rewritten. Microbiology 1999, 145, 767-779.

16. Valentine, R.C.; Valentine, D.L. Omega-3 fatty acids in cellular membranes: A unified concept. Prog. Lipid Res. 2004, 43, 383-402.

17. Okuyama, H.; Orikasa, Y.; Nishida, T. Significance of antioxidative functions of eicosapentaenoic and docosahexaenoic acids in marine microorganisms. Appl. Environ. Microbiol. 2008, 74, 570-574.

18. Miyashita, K.; Nara, E.; Ota, T. Oxidative stability of polyunsaturated fatty acids in an aqueous solution. Biosci. Biotechnol. Biochem. 1993, 57, 1638-1640.

19. Yazu, K.; Yamamoto, Y.; Niki, E.; Ukegawa, K. Mechanism of lower oxidizability of eicosapentaenoate than linoleate in aqueous micelles. Lipids 1998, 33, 597-600.

20. Lovern, J.A. Fat metabolism in fishes: The fats of some plankton crustacea. Biochem. J. 1935, 30, 387-390.

21. Dalsgaard, J.; St John, M.; Kattner, G.; Muller-Navarra, D.; Hagen, W. Fatty acid trophic markers in the pelagic marine environment. Adv. Mar. Biol. 2003, 46, 225-340.

22. Sinensky, M. Homeoviscous adaptation-A homeostatic process that regulates the viscosity of membrane lipids in Escherichia coli. Proc. Natl. Acad. Sci. USA 1974, 71, 522-525.

23. MacElroy, M. Some comments on the evolution of extremophiles. Biosytems 1974, 6, 74-75. 
24. Bowers, K.; Mesbah, N.; Wiegel, J. Biodiversity of poly-extremophilic bacteria: Does combining the extremes of high salt, alkaline $\mathrm{pH}$ and elevated temperature approach a physico-chemical boundary for life? Saline Syst. 2009, 5, 9.

25. Delong, E.F.; Yayanos, A.A. Properties of the glucose-transport system in some deep-sea bacteria. Appl. Environ. Microbiol. 1987, 53, 527-532.

26. Kuypers, M.M.M.; Blokker, P.; Erbacher, J.; Kinkel, H.; Pancost, R.D.; Schouten, S.; Sinninghe Damsté, J.S. Massive expansion of marine Archaea during a mid-cretaceous oceanic anoxic event. Science 2001, 293, 92-95.

27. Lipp, J.S.; Morono, Y.; Inagaki, F.; Hinrichs, K.-U. Significant contribution of Archaea to extant biomass in marine subsurface sediments. Nature 2008, 454, 991-994.

28. Canganella, F.; Wiegel, J. Extremophiles: From abyssal to terrestrial ecosystems and possibly beyond. Naturwissenschaften 2011, 98, 253-279.

29. Thomas, D.N.; Dieckmann, G.S. Antarctic Sea Ice-A habitat for extremophiles. Science 2002, 295, 641-644.

30. Metz, J.G.; Roessler, P.; Facciotti, D.; Levering, C.; Dittrich, F.; Lassner, M.; Valentine, R.; Lardizabal, K.; Domergue, F.; Yamada, A.; Yazawa, K.; Knauf, V.; Browse, J. Production of polyunsaturated fatty acids by polyketide synthases in both prokaryotes and eukaryotes. Science 2001, 293, 290-293.

31. Bowman, J.P.; Gosink, J.J.; McCammon, S.A.; Lewis, T.E.; Nichols, D.S.; Nichols, P.D.; Skerratt, J.H.; Staley, J.T.; McMeekin, T.A. Colwellia demingiae sp. nov., Colwellia hornerae sp. nov., Colwellia rossensis sp. nov. and Colwellia psychrotropica sp. nov.: Psychrophilic Antarctic species with the ability to synthesize docosahexaenoic acid (22:603). Int. J. Syst. Bacteriol. 1998, 48, 1171-1180.

32. Shulse, C.N.; Allen, E.E. Widespread occurrence of secondary lipid biosynthesis potential in microbial lineages. PLoS One 2011, 6, e20146.

33. De Rosa, M.; Gambacorta, A.; Huber, R.; Lanzotti, V.; Nicolaus, B.; Stetter, K.O.; Trincone, A. Microbiology of Extreme Environments and Its Potential for Biotechnology; da Costa, M.S., Duarte, J.C., Williams, R.A.D., Eds.; Springer: New York, NY, USA, 1989; pp. 167-173.

34. Wilson, Z.E.; Brimble, M.A. Molecules derived from the extremes of life. Nat. Prod. Rep. 2009, $26,44-71$.

35. Stetter, K.O. Extremophiles and their adaptation to hot environments. FEBS Lett. 1999, 452, 22-25.

36. Uda, I.; Sugai, A.; Itoh, Y.H.; Itoh, T. Variation in molecular species of polar lipids from Thermoplasma acidophilum depends on growth temperature. Lipids 2001, 36, 103-105.

37. Nicolas, J. A molecular dynamics study of an archaeal tetraether lipid membrane: Comparison with a dipalmitoylphosphatidylcholine lipid bilayer. Lipids 2005, 40, 1023-1030.

38. Van de Vossenberg, J.L.C.M.; Driessen, A.J.M.; Grant, D.; Konings, W.N. Lipid membranes from halophilic and alkali-halophilic Archaea have a low $\mathrm{H}^{+}$and $\mathrm{Na}^{+}$permeability at high salt concentration. Extremophiles 1999, 3, 253-257.

39. Vreeland, R.H.; Anderson, R.; Murray, R.G. Cell wall and phospholipid composition and their contribution to the salt tolerance of Halomonas elongata. J. Bacteriol. 1984, 160, 879-883.

40. Russell, N.J. Adaptive modifications in membranes of halotolerant and halophilic microorganisms. J. Bioenerg. Biomembr. 1989, 21, 93-113. 
41. Coker, J.A.; DasSarma, P.; Kumar, J.; Müller, J.; DasSarma, S. Transcriptional profiling of the model Archaeon Halobacterium sp. NRC-1: Responses to changes in salinity and temperature. Saline Sys. 2007, 3, 6.

42. McElhaney, R.N. The effects of alterations in the physical state of the membrane lipids on the ability of Acholeoplasma laidlawii B to grow at different temperatures. J. Mol. Biol. 1974, 84, 145-157.

43. Fang, J.; Barcelona, M.J.; Nogi, Y.; Kato, C. Biochemical implications and geochemical significance of novel phospholipids of the extremely barophilic bacteria from the Marianas Trench at 11,000 m. Deep-Sea Res. 2000, 47, 1173-1182.

44. Son, B.; Kim, J.; Choi, H. A new diacylgalactolipid containing 4Z-16:1 from the marine cyanobacterium Oscillatoria sp. Lipids 2001, 36, 427-429.

45. Dembitsky, V.M.; Srebnik, M. Natural halogenated fatty acids: Their analogues and derivatives. Prog. Lipid Res. 2002, 41, 315-367.

46. Wu, M.; Milligan, K.E.; Gerwick, W.H. Three new malyngamides from the marine cyanobacterium Lyngbya majuscula. Tetrahedron 1997, 53, 15983-15990.

47. Kaneda, T. Iso- and Anteiso-fatty acids in bacteria: Biosynthesis, function, and taxonomic significance. Microbiol. Rev. 1991, 55, 288-302.

48. Wollenweber, H.W.; Rietschel, E.T.; Hofstad, T.; Weintraub, A.; Lindbert., A.A. Nature, type of linkage, quantity, and absolute configuration of (3-hydroxy) fatty acids in lipopolysaccharides from Bacteroides fragilis NCTC 9343 and related strains. J. Bacteriol. 1980, 144, 898-903.

49. Sanchez, L.M.; Wong, W.R.; Riener, R.M.; Schulze, C.J.; Linington, R.G. Examining the fish microbiome: Vertebrate-derived bacteria as an environmental niche for the discovery of unique marine natural products. Plos One 2012, 7, e35398.

50. Spiteller, G. Furan fatty acids: Occurrence, synthesis, and reactions. Are furan fatty acids responsible for the cardioprotective effects of a fish diet? Lipids 2005, 40, 755-771.

51. Shirasaka, N.; Nishi, K.; Shimizu, S. Biosynthesis of furan fatty acids (F-acids) by a marine bacterium, Shewanella putrefaciens. Biochim. Biophys. Acta 1997, 1346, 253-260.

52. Poralla, K.; König, W.A. The occurrence of $\omega$-cycloheptane fatty acids in a thermo-acidophilic bacillus. FEMS Microbiol. Lett. 1983, 16, 303-306.

53. Kates, M.; Moldoveanu, N.; Stewart, L.C. On the revised structure of the major phospholipid of Halobacterium salinarium. Biochim. Biophys. Acta 1993, 1169, 46-53.

54. Aries, E.; Doumenq, P.; Artaud, J.; Molinet, J.; Bertrand, J.C. Occurrence of fatty acids linked to non-phospholipid compounds in the polar fraction of a marine sedimentary extract from Carteau cove, France. Org. Geochem. 2001, 32, 193-197.

55. Shirasaka, N.; Nishi, K.; Shimizu, S. Occurrence of a furan fatty acid in marine bacteria. Biochim. Biophys. Acta 1995, 1258, 225-227.

56. Alvarez, H.M.; Pucci, O.H.; Steinbüchel, A. Lipid storage compounds in marine bacteria. Appl. Microbiol. Biotechnol. 1997, 47, 132-139.

57. Nakano, M.; Iehata, S.; Tanaka, R.; Maeda, H. Extracellular neutral lipids produced by the marine bacteria Marinobacter sp. Biocontrol Sci. 2012, 17, 69-75. 
58. De Carvalho, C.C.C.R.; ds Fonseca, M.M.R. Degradation of hydrocarbons and alcohols at different temperatures and salinities by Rhodococcus erythropolis DCL14. FEMS Microbiol. Ecol. 2005, 51, 389-399.

59. Decho, A.W. Microbial biofilms in intertidal systems: An overview. Cont. Shelf Res. 2000, 20, 1257-1273.

60. Otto Ortega-Morales, B.; Jesus Chan-Bacab, M.; del Carmen De la Rosa-Garcia, S.; Carlos Camacho-Chab, J. Valuable processes and products from marine intertidal microbial communities. Curr. Opin. Biotechnol. 2010, 21, 346-352.

61. Freese, E.; Rütters, H.; Köster, J.; Rullkötter, J.; Sass, H. Gammaproteobacteria as a possible source of eicosapentaenoic acid in anoxic intertidal sediments. Microb. Ecol. 2009, 57, 444-454.

62. Sherr, E.B.; Sherr, B.F.; Albright, L.J. Bacteria: Link or sink? Science 1987, 235, 88a.

63. Phillips, N.W. Role of different microbes and substrates as potential suppliers of specific, essential nutrients to marine detritivores. Bull. Mar. Sci. 1984, 35, 283-298.

64. Ahlgren, G.; Lundstedt, L.; Brett, M.; Forsberg, C. Lipid composition and food quality of some freshwater phytoplankton for cladoceran zooplankters. J. Plankton Res. 1990, 12, 809-818.

65. Volkman, J.V. Sterols in microorganisms. Appl. Microbiol. Biotechnol. 2003, 60, 495-506.

66. Brett, M.; Müller-Navarra, D. The role of highly unsaturated fatty acids in aquatic foodweb processes. Freshw. Biol. 1997, 38, 483-499.

67. Albers, C.S.; Kattner, G.; Hagen, W. The compositions of wax esters, triacylglycerols and phospholipids in Arctic and Antarctic copepods: Evidence of energetic adaptations. Mar. Chem. 1996, 55, 347-358.

68. Yazawa, K. Production of eicosapentaenoic acid from marine bacteria. Lipids 1996, 31, S297-S300.

69. Nichols, D.; Bowman, J.; Sanderson, K.; Nichols, C.M.; Lewis, T.; McMeekin, T.; Nichols, P.D. Developments with Antarctic microorganisms: Culture collections, bioactivity screening, taxonomy, PUFA production and cold-adapted enzymes. Curr. Opin. Biotechnol. 1999, 10, 240-246.

70. Wallis, J.G.; Watts, J.L.; Browse, J. Polyunsaturated fatty acid synthesis: What will they think of next? Trends Biochem. Sci. 2002, 27, 467-473.

71. Ustach, J.F. Algae, bacteria and detritus as food for the harpacticoid copepod, Heteropsyllus pseudonunni Coull and Palmer. J. Exp. Mar. Biol. Ecol. 1982, 64, 203-214.

72. Sogard, S.M. Utilization of meiofauna as a food source by a grassbed fish, the spotted dragonet Callionymus pauciradiatus. Mar. Ecol. Prog. Ser. 1984, 17, 183-191.

73. Decho, A.W. Water-cover influences on diatom ingestion rates by meiobenthic copepods. Mar. Ecol. Prog. Ser. 1986, 33, 139-146.

74. Norsker, N.-H.; Støttrup, J.G. The importance of dietary HUFAs for fecundity and HUFA content in the harpacticoid, Tisbe holothuriae Humes. Aquaculture 1994, 125, 155-166.

75. De Troch, M.; Mees, J.; Wakwabi, E. Diets of abundant fishes from beach seine catches in seagrass beds of a tropical bay (Gazi Bay, Kenya). Belg. J. Zool. 1998, 128, 135-154.

76. Buffan-Dubau, E.; Carman, K.R. Diel feeding behavior of meiofauna and their relationships with microalgal resources. Limnol. Oceanogr. 2000, 45, 381-395.

77. De Troch, M.; Boeckx, P.; Cnudde, C.; Van Gansbeke, D.; Vanreusel, A.; Vincx, M.; Caramujo, M.J. Bioconversion of fatty acids at the basis of marine food webs: Insights from a compound-specific stable isotope analysis. Mar. Ecol. Prog. Ser. 2012, 465, 53-67. 
78. Stevens, C.J.; Limén, H.; Pond, D.W.; Gélinas, Y.; Juniper, S.K. Ontogenetic shifts in the trophic ecology of two alvinocaridid shrimp species at hydrothermal vents on the Mariana Arc, western Pacific Ocean. Mar. Ecol. Prog. Ser. 2008, 356, 225-237.

79. Šajbidor, J.; Dobroñová, S.; Čertík, M. Arachidonic acid production by Mortierella sp. S-17 influence of C/N ratio. Biotechnol. Lett. 1990, 12, 455-456.

80. Nichols, D.S.; Nichols, P.D.; McMeekin, T.A. Polyunsaturated fatty acids in Antarctic bacteria. Antarct. Sci. 1993, 5, 149-160.

81. Yano, Y.; Nakayama, A.; Yoshida, K. Distribution of polyunsaturated fatty acids in bacteria present in intestines of deep-sea fish and shallow-sea poikilothermic animals. Appl. Environ. Microbiol. 1997, 63, 2572-2577.

82. Caron, D.A. Symbiosis and Mixotrophy among Pelagic Microorganisms. In Microbial Ecology of the Oceans; Kirchman, D.L., Ed.; Wiley-Liss: New York, NY, USA, 2000; pp. 495-523.

83. Sherr, E.B.; Sherr, B.F. Heterotrophic dinoflagellates: A significant component of microzooplankton biomass and major grazers of diatoms in the sea. Mar. Ecol. Prog. Ser. 2007, 352, 187-197.

84. Strom, S.L. Bacterivory: Interactions between Bacteria and Their Grazers. In Microbial Ecology of the Oceans; Kirchman, D.L., Ed.; Wiley-Liss: New York, NY, USA, 2000; pp. 286-351.

85. Caron, D.A.; Goldman, J.C. Nutrient Regeneration. In Ecology of Marine Protozoa; Capriulo, G.M., Ed.; Oxford University Press: New York, NY, USA, 1990; pp. 283-306.

86. Stoecker, D.K.; McDowell, C. Predation on protozoa: Its importance to zooplankton. J. Plankton Res. 1990, 12, 891-908.

87. Gifford, D.J.; Dagg, M.J. The microzooplankton-mesozooplankton link: Consumption of planktonic protozoa by the calanoid copepods Acartia tonsa Dana and Neocalanus plumchrus Murkukawa. Mar. Microb. Food Webs 1991, 5, 161-177.

88. Fauré-Fremiet, E. Contribution à la connaissance des infusoires planctoniques. Bull. Biol. Fr. Bel. 1924, 6 (Suppl.), 1-171.

89. Pomeroy, L.R. The ocean's food web, a changing paradigm. Bioscience 1974, 24, 499-504.

90. Azam, F.; Fenchel, T.; Field, J.G.; Gray, J.S.; Meyer-Reil, L.A.; Thingstad, F. The ecological role of water-column microbes in the sea. Mar. Ecol. Prog. Ser. 1983, 10, 257-263.

91. Sherr, E.; Sherr, B.F. Role of microbes in pelagic food webs: A revised concept. Limnol. Oceanogr. 1988, 33, 1225-1227.

92. Li, W.K.W.; Rao, D.V.S.; Harrison, W.G.; Smith, J.C.; Cullen, J.J.; Irwin, B.; Platt, T. Autotrophic picoplankton in the tropical ocean. Science 1983, 219, 292-295.

93. Stockner, J.G.; Antia, N.J. Algal picoplankton from marine and freshwater ecosystems: A multidisciplinary perspective. Can. J. Fish. Aquat. Sci. 1986, 43, 2472-2503.

94. Weisse, T. Dynamics of autotrophic picoplankton in marine and freshwater ecosystems. $A d v$. Microb. Ecol. 1993, 13, 327-369.

95. Desvilettes, C.; Bec, A. Formation and Transfer of Fatty Acids in Aquatic Microbial Food Webs: Role of Heterotrophic Protists. In Lipids in Aquatic Ecosystems; Kainz, M., Brett, M.T., Arts, M.T., Eds.; Springer: New York, NY, USA, 2009; pp. 25-42. 
96. Breteler, W.C.M.K.; Schogt, N.; Baas, M.; Schouten, S.; Kraay, G.W. Trophic upgrading of food quality by protozoans enhancing copepod growth: Role of essential lipids. Mar. Biol. 1999, 135, 191-198.

97. Bec, A.; Martin-Creuzburg, D.; Elert, E.V. Trophic upgrading of autotrophic picoplankton by the heterotrophic nanoflagellate Paraphysomonas sp. Limnol. Oceanogr. 2006, 51, 1699-1707.

98. Sanders, R.W.; Wickham, S.A. Planktonic protozoa and metazoa: Predation, food quality and population control. Mar. Microb. Food Webs 1993, 7, 197-223.

99. Veloza, A.; Chu, F.-L.; Tang, K. Trophic modification of essential fatty acids by heterotrophic protists and its effects on the fatty acid composition of the copepod Acartia tonsa. Mar. Biol. 2006, 148, 779-788.

100. Zhukova, N.V.; Kharlamenko, V.I. Sources of essential fatty acids in the marine microbial loop. Aquat. Microb. Ecol. 1999, 17, 153-157.

101. Vera, A.; Desvilettes, C.; Bec, A.; Bourdier, G. Fatty acid composition of freshwater heterotrophic flagellates: An experimental study. Aquat. Microb. Ecol. 2001, 25, 271-279.

102. Broglio, E.; Jónasdóttir, S.H.; Calbet, A.; Jakobsen, H.H.; Saiz, E. Effect of heterotrophic versus autotrophic food on feeding and reproduction of the calanoid copepod Acartia tonsa: Relationship with prey fatty acid composition. Aquat. Microb. Ecol. 2003, 31, 267-278.

103. Bec, A.; Desvilettes, C.; Vera, A.; Fontvielle, D.; Bourdier, G. Nutritional value of different food sources for the bennthic daphnidae Simocephalus vetulus: Role of fatty acids. Arch. Hydrobiol. 2003, 156, 145-163.

104. Ratledge, C. Fatty acid biosynthesis in microorganisms being used for single cell oil production. Biochimie 2004, 86, 807-815.

105. Kobayashi, T.; Sakaguchi, K.; Matsuda, T.; Abe, E.; Hama, Y.; Hayashi, M.; Honda, D.; Okita, Y.; Sugimoto, S.; Okino, N.; et al. Increase of eicosapentaenoic acid in Thraustochytrids through thraustochytrid ubiquitin promoter-driven expression of a fatty acid $\Delta 5$ desaturase gene. Appl. Environ. Microbiol. 2011, 77, 3870-3876.

106. Parrish, C.C.; Whiticar, M.; Puvanendran, V. Is w6 docosapentaenoic acid an essential fatty acid during early ontogeny in marine fauna? Limnol. Oceanogr. 2007, 52, 476-479.

107. Raghukumar, S. Thraustochytrid marine protists: Production of PUFAs and other emerging technologies. Mar. Biotechnol. 2008, 10, 631-640.

108. Volkman, J.K. Sterols and other triterpenoids: Source specificity and evolution of biosynthetic pathways. Org. Geochem. 2005, 36, 139-159.

109. Martin-Creuzburg, D.; Elert, E.V. Ecological Significance of Sterols in Aquatic Food Webs. In Lipids in Aquatic Ecosystems; Kainz, M., Brett, M.T., Arts, M.T., Eds.; Springer: New York, NY, USA, 2009; pp. 43-64.

Samples Availability: Available from the authors.

(C) 2012 by the authors; licensee MDPI, Basel, Switzerland. This article is an open access article distributed under the terms and conditions of the Creative Commons Attribution license (http://creativecommons.org/licenses/by/3.0/). 